\title{
A national survey of psychiatrists' attitudes towards the physical examination
}

Sarah Baillon ${ }^{12}$ and Jonathan Murray ${ }^{3}$

${ }^{1}$ Leicestershire Partnership NHS Trust, Leicester, UK

${ }^{2}$ Department of Health Sciences, University of Leicester, Leicester, UK

${ }^{3}$ The Manthorpe Centre, Lincolnshire Partnership Foundation NHS Trust, Grantham, UK.

This work was carried out in Leicestershire Partnership NHS Trust, Leicester, UK.

Dr Sarah Baillon (corresponding author)

Senior Research Associate

Research \& Development Team

Leicestershire Partnership NHS Trust

Swithland House

352 London Road

Leicester, LE2 2PL

Tel. 01162955805

Email: sarah.baillon@leicspart.nhs.uk

Dr Jonathan Murray

The Manthorpe Centre

Lincolnshire Partnership Foundation NHS Trust

Grantham Hospital Site

101 Manthorpe Road

Grantham,

Lincolnshire, UK, NG31 8DG.

Tel. 07532476048

Email: jonathan.murray@lpft.nhs.uk

Word count of manuscript: 2808 (excluding Abstract, Tables and References) 


\begin{abstract}
Background

Studies have shown that most psychiatric patients do not receive a thorough physical examination $(\mathrm{PE})$.

Aims
\end{abstract}

To explore factors contributing to the underperformance of the PE on psychiatric patients.

\title{
Method
}

All psychiatrists in the UK who were registered or affiliated to the Royal College of Psychiatrists were invited to complete an online survey regarding their attitudes towards PEs in psychiatry.

\section{Results}

Responses from $15 \%$ of the psychiatrists showed that most $(89 \%)$ believe that the PE is important. The majority (61\%) indicated that their PE skills had diminished since working in psychiatry and this was reported more by senior psychiatrists than junior trainees (64\% vs 49\%). Most respondents considered that the PE should not be done by another type of health professional (45\% vs 28\%).

\section{Conclusions}

Likely reasons for poor performance of PEs include shortage of time and equipment, challenges associated with agitated and uncooperative patients, the perceived incongruence of the PE with the patient's presenting symptoms and a degree of skill atrophy, especially in senior psychiatrists which is leading to lack of supervision of junior trainees in this area. Further research is needed to investigate if strategies addressing these factors would improve the standard of PEs on psychiatric patients. 
Declaration of interest: This survey received no specific funding and all authors have no conflict of interest to report.

Keywords: physical examination, psychiatry, physical health, attitudes, psychiatrists, clinical skills 


\section{Introduction}

There is now abundant evidence that people with severe mental illness (SMI) have an increased risk of comorbid physical health problems (Correll et al, 2017; Vancampfort et al 2016; Vancampfort et al, 2015). Indeed, the life expectancy of those with SMI has been estimated to be up to 25 years shorter compared to the general population and there is some evidence that the mortality gap is not closing (Lawrence, Hancock, \& Kisely, 2013; Thornicroft, 2013).

Several reasons have been identified for this disparity including unhealthy lifestyle choices such as smoking, poor diet, lack of exercise, substance misuse and unsafe sexual practices, the side effects of psychotropic medication and the under-utilisation of medical services in general (De Hert, Cohen, et al., 2011; Dipasquale et al 2013; Druss, Zhao, Von Esenwein, Morrato, \& Marcus, 2011; Jones, Howard, \& Thornicroft, 2008; Vancampfort et al, 2017).

The assessment of patients in the psychiatric outpatient clinic or following admission to a psychiatric ward provides an opportunity to check their physical health by taking a history, performing a physical examination (PE), carrying out various investigations and obtaining collateral information. However, many psychiatric patients, for example those with cognitive deficits or poor social skills, have difficulty describing their symptoms and are less likely to complain about them than the general population (Phelan, Stradins, \& Morrison, 2001; Sokal et al., 2004). In view of this it is important that a PE is undertaken in order to exclude physical disease as a cause for the patient's psychiatric symptoms and identify coexistent conditions which could hinder the patient's recovery and influence choice of treatment (Reeves, Pendarvis, \& Kimble, 2000; Waern et al., 2002). A PE also enables baseline data to be recorded for comparison should the patient's physical state change at a later date. 
Studies that have assessed the quality of this aspect of care have concluded that most psychiatric inpatients do not receive a thorough PE (Hodgson \& Adeyemo, 2004; Murray \& Baillon, 2013; Pettipher \& Ovens, 2015; Rigby \& Oswald, 1986; Vanezis \& Manns, 2010). A survey of psychiatrists working in Leicestershire in the UK in 2012 indicated that likely reasons for poor performance of the PE include a shortage of time and equipment, challenges associated with agitated or uncooperative patients and possibly a degree of skill atrophy, especially in senior psychiatrists (Murray, Baillon, Bruce, \& Velayudhan, 2015). However, this survey was limited to a single NHS Trust and the authors considered that a larger national survey would provide more information on which to base efforts to improve standards.

\section{Method}

The Health Research Authority was consulted and confirmed that the project would not require HRA approval. The Research Permission Services for all 3 Devolved Nations (Wales, Scotland and Northern Ireland) were also informed and confirmed that no approval was required for the survey to be carried out in their areas.

In May 2017 the Royal College of Psychiatrists (RCP) sent an invitation email to all their current UK members (including retired members). The email invited members to complete a brief online survey regarding the attitudes of psychiatrists towards physical examinations in psychiatry and included a link to the survey which was hosted on an independent survey website (SmartSurvey).

The Survey started with an explanation of the purpose of the survey and stated that it was anonymous and voluntary to complete. The respondents were then required to indicate their consent to participate, before proceeding to the survey questions. A second invitation email 
was sent out one month later, encouraging RCP members to complete the survey, if they had not already done so. Four weeks after the second email the survey was closed.

The questionnaire obtained basic information about the respondent and then included questions with categorical and Likert scale responses. Questions were based on a range of issues included in a previous survey (Murray, et al., 2015) and included items on physical examinations in their current (or if retired, most recent) job and on their views about physical examinations in psychiatry. Respondents were asked about their physical examination skills and supervision of junior trainees in this domain. The questions used are shown in Table 3. Respondents were invited to record any thoughts or comments in a free text item at the end of the survey. All data were analysed descriptively using IBM SPSS Statistics version 20. Univariate analyses were used to find significant associations between demographic data and item responses using Chi-squared tests and Fisher's exact tests when the expected cell value was less than 5 .

\section{Results}

The invitation email was sent by the RCP to 13,873 UK members. Complete or partial responses were received from 2072 individuals, giving a response rate of $14.9 \%$. 1024 (49.4\%) respondents were male. 1858 (89.7\%) were currently employed as psychiatrists, 194 $(9.4 \%)$ were retired and $20(1 \%)$ were not working. [Table 1 near here]

Table 1 shows the number of respondents working in each speciality and their grade. Table 2 shows the frequency that respondents reported carrying out PEs on psychiatric patients. Tables 3 and 4 show the responses to the items in the survey. [Table 2 near here]

There was significantly higher proportion of female junior trainees than female senior psychiatrists (i.e. consultants, non-consultant career grades, psychiatrists in senior academic 
posts and senior trainees) (48\% senior vs $62 \%$ junior; Pearson Chi-squared $=23.1, \mathrm{df}=1$, $\mathrm{P}<0.001$ ). A higher proportion of females reported not having access to an appropriate chaperone when conducting a $\mathrm{PE}$ on an inpatient (Pearson Chi-squared $=6.3, \mathrm{df}=1, \mathrm{P}<0.01$ ). There was no significant difference in the proportion of male and female psychiatrists who reported feeling 'always or usually' intimidated when carrying out PE on inpatients (Pearson Chi-squared $=0.06, \mathrm{df}=1, \mathrm{P}=0.80$ ) or outpatients (Pearson Chi-squared $=0.27, \mathrm{df}=1, \mathrm{P}=0.61$ ). A higher proportion of females rated their proficiency in PE skills as 'mediocre, poor or very poor' (Pearson Chi-squared $=16.4, \mathrm{df}=1, \mathrm{P}<0.001$ ) and a greater number of females were in favour of the PE being performed by another type of professional (Pearson Chi-squared = 19.0, $\mathrm{df}=2, \mathrm{P}<0.001)$.

A significantly higher proportion of junior trainees indicated they routinely carry out PE on inpatients than senior psychiatrists (Pearson Chi-squared $=533.0, \mathrm{df}=1, \mathrm{P}<0.001$ ). $\mathrm{A}$ significantly higher proportion of senior staff rated their PE skills as "mediocre, poor or very poor" (Pearson Chi-squared $=80.1, \mathrm{df}=1, \mathrm{P}<0.001$ ) and significantly more senior psychiatrists felt that their PE skills had deteriorated since working in psychiatry (Pearson Chisquared $=30.2, \mathrm{df}=2, \mathrm{P}<0.001)$. More senior staff than junior trainees felt that a teaching session in PE skills should be included in trainees' induction courses (Pearson Chisquared $=41.2, \mathrm{df}=2, \mathrm{P}<0.001)$. [Tables 3 and 4 near here]

\section{Discussion}

This national survey, which obtained views from psychiatrists in all the main sub-specialities, clarifies considerably the factors contributing to the standard of PEs performed on psychiatric patients. The results show, as did an earlier regional survey, that most psychiatrists view the PE as important, think that skills in this domain should be part of their core competencies which should be maintained throughout their career, and do not believe that it has a negative 
effect on the patient (Murray, et al., 2015). The survey responses also indicate that most psychiatrists rate their PE competencies as good or mediocre and that they are in favour of using structured forms to document the PE findings, a practice which has been shown to increase the amount of information recorded (Murray \& Baillon, 2013).

The study shed further light upon the factors likely to be contributing to the underperformance of the PEs. Like the original survey, a substantial number of respondents complained about lack of time and examination equipment both in the outpatient clinics and the wards. Also, a significant number of respondents admitted that they sometimes feel intimidated whilst examining psychiatric patients, - more so in the inpatient than the outpatient setting. However, unlike the Leicestershire survey, this group did not contain a higher proportion of female doctors. In addition, the study revealed that a large number of respondents find the PE incongruent with the patient's presenting symptoms. Moreover, like the original survey, the majority of respondents stated that their PE skills had deteriorated since starting work in psychiatry and this group included a higher proportion of senior psychiatrists compared to junior trainees.

\section{Limitations}

The response rate was only $15 \%$ and therefore the results should be interpreted with caution. It is possible that the low response rate could have skewed the results in favour of those psychiatrists who have a greater than average interest in the physical healthcare of their patients. However, doctors are a professional group with low survey response rates in general and it has been noted that the relationship between nonresponse and nonresponse bias is a complex one (Cunningham et al., 2015; Groves \& Peytcheva, 2008; Livingston \& Wislar, 2012). 
Another limitation of the study was that the opportunity to give free text responses was only provided at the end of the survey rather than after each question. This was done to make the survey easier to complete but more information may have been obtained if the respondents could have made comments at each stage of the survey.

\section{Implications for clinical practice}

So how can the results from this survey be used constructively to inform improvements in the PEs performed on psychiatric patients? One longstanding problem is the shortage of equipment which is clearly unacceptable in the inpatient setting where the physical healthcare of a patient is ultimately the psychiatric team's responsibility (Hodgson, Belgamwar, \& Krishna, 2006). This could be addressed by assigning responsibility for obtaining, securing and maintaining PE equipment to certain staff members and regularly auditing this. Similarly the frequent absence of an examination couch and the difficulties that doctors experience in gaining access to a chaperone, problems which are more prevalent outpatient than inpatient settings, need to be addressed in order to facilitate the performance of PEs.

Another contributory factor identified in the survey but not taken into account during previous audits, is the intimidating effect that some patients may have on the psychiatrist performing the PE. The Royal College of Psychiatrists recommends that every patient should have a comprehensive PE within 24 hours of admission but the vast majority of the respondents indicated that the patient's mental state should have a bearing on the type of PE a psychiatrist performs e.g. an external inspection only when a patient is totally uncooperative or too hostile to allow any direct contact (Garden, 2005; The Royal College of Psychiatrists, 2009). Most of the respondents who commented on this issue were in favour of setting standards for a basic screening examination, specific to each sub-speciality, but had reservations about the need for a full PE, preferring an appropriate PE based on the patient's 
presentation. A number of respondents stressed the importance of having a protocol in place to ensure that the patient is revisited at the earliest opportunity if an adequate PE was not performed at the time of admission.

Another relevant factor which has received scant attention in the literature is the apparent incongruence between the PE and the patient's presenting symptoms, a perception which in the words of one respondent leads to the PE being "the most cursory part of the clerking". We believe that this problem could be addressed during the psychiatric trainee induction course by focussing on various topics such as the physical signs that would help diagnose an organic condition, the common physical health consequences of SMI and its pharmacological treatments and the ways of approaching potentially violent patients and those with histories of physical and/or sexual abuse.

The free text responses in this survey revealed considerable concern about the problem of skill atrophy, particularly in the domain of the neurological examination. Some respondents opined that the decline of their PE skills began at the start of their higher training and some psychiatrists admitted that they had not examined a patient for over 20 years. In the survey most senior psychiatrists said that they had not observed the PE skills of their trainees during the last year, for example as part of a workplace based assessment, often admitting that they lacked confidence in this area and thought that the trainees' skills were better than their own. It would seem that this problem is not restricted to the UK because a survey of the use of direct observation in a Canadian Psychiatric training program revealed that PE skills were observed less frequently than skills in other clinical contexts (Madan, Conn, Dubo, Voore, \& Wiesenfeld, 2012). Some respondents in the UK survey remarked that if senior psychiatrists lose their skills in this area they are in a weak position to change any negative attitudes that a junior trainee might have. Although the vast majority of respondents were in favour of maintaining their PE skills by attending refresher courses a number of them stressed that any 
skills honed on a course would be quickly lost if they are not incorporated into regular clinical practice and that therefore a suitable mechanism has to be found to achieve this.

Some of the respondents pointed out that the issue of the PE should not be viewed in isolation from the provision of physical healthcare as a whole. For example, several junior trainees frankly admitted that they are disinclined to look for physical signs in their inpatients because they lack the knowledge and experience to manage them adequately and there are no senior members of the psychiatric team capable of assisting them. Several respondents lamented that in this area psychiatric services are not reciprocally supported i.e. general hospitals benefit from psychiatric liaison services but medical and surgical liaison services are not routine in psychiatric settings. These comments tally with the results of a survey which showed that there was generally a positive attitude to the development of a reciprocal liaison service (Davies, 2000). The Royal College of Psychiatrists has stated that developing the role of liaison physicians to provide care to psychiatric inpatients, including long-stay patients in secure settings, and patients in the community, who may not be in regular contact with their GP, would be a significant advance in the care of people with SMI (The Royal College of Psychiatrists, 2013).

We believe that the findings of this UK-wide survey, if acted upon, could significantly improve the PEs performed by psychiatrists. However, such measures would be rendered obsolete if the responsibility of the PE was transferred to another professional such as a physician or nurse practitioner, a change opted for by a substantial minority $(28 \%)$ of the respondents. The reasons given for this decision included time constraints, being overburdened with purely psychiatric aspects of care and the belief that the PE should be done by a professional who maintains a high level of proficiency by doing them regularly. In contrast to this, a relatively large number of respondents stated that they 'feel strongly' that this step should never be taken. A comment that was repeatedly made was that psychiatrists are first 
and foremost doctors and that they are uniquely placed in the multidisciplinary team to follow the biopsychosocial model and form a holistic view of the patient's presentation (Craddock et al., 2008; Shah \& Mountain, 2007). One respondent asserted that relinquishing this aspect of care would "sound the death knell of the profession" and another stated that it would "open the gateway to psychiatrists being replaced by a combination of pharmacists, psychologists and nurse practitioners". The changes in the roles of healthcare professionals which have been promoted by recent governments e.g. the extension of prescribing to nurses and pharmacists, suggest that these concerns should not be dismissed lightly (Coombes, 2008; Imison, Castle-Clarke, \& Watson, 2016; Patel et al., 2009). Another respondent commented that "being able to perform a PE improves the credibility of psychiatrists as doctors and benefits their relationships with colleagues in other specialities". Clearly handing over responsibility for the physical care of inpatients is unlikely to increase the low status of psychiatry as perceived by medical students and foundation trainees, a problem that is regarded as one of the most important factors affecting recruitment (Brown, Addie, \& Eagle, 2007; Harper \& Roman, 2017). It is perhaps time for the psychiatric profession to have a thorough debate on the subject.

\section{Conclusion}

There is now ample evidence of a marked disparity in physical health between patients with SMI and the general population, for which a variety of interrelated causes have been identified. This survey has highlighted a number of factors relating to one aspect of the problem - the underperformance of PEs in psychiatric patients. Some of these factors, such as the shortage of equipment, can be readily addressed but others, such as PE skill atrophy amongst senior psychiatrists and the paucity of physical health liaison services, will require changes in training, working practices and service provision. Further research and audit are 
needed to investigate whether strategies addressing these issues would improve the standard of PEs on psychiatric patients. 


\section{References}

Brown, T., Addie, K., \& Eagle, J. (2007). Recruitment into psychiatry: views of consultants in Scotland. Psychiatric Bulletin, 31, 411-413.

Coombes, R. (2008). Dr Nurse will see you now British Medical Journal, 337, a1522. doi:

\section{https://doi.org/10.1136/bmj.a1522}

Correll, C.U., Solmi, M., Veronese, N., Bortolato, B., Rosson, S., Santonastaso, P., ThapaChhetri, N., Fornaro, M., Gallicchio, D., Collantoni, E., Pigato, G., Favaro, A., Monaco, F., Kohler, C., Vancampfort, D., Ward, P.B., Gaughran, F., Carvalho, A.F., Stubbs, B. (2017) Prevalence, incidence and mortality from cardiovascular disease in patients with pooled and specific severe mental illness: a large-scale meta-analysis of 3,211,768 patients and 113,383,368 controls. World Psychiatry, 16(2), 163-180.

Craddock, N., Antebi, D., Attenburrow, M.-J., Bailey, A., Carson, A., Cowen, P., et al. (2008). Wake-up call for British Psychiatry. British Journal of Psychiatry, 193, 6-9. doi: 10.1192/bjp.bp.108.053561

Cunningham, C., Quan, H., Hemmelgarn, B., Noseworthy, T., Beck, C., Dixon, E., et al. (2015). Exploring physician specialist response rates to web-based surveys. BMC Medical Research Methodology, 15, 32.

Davies, M. (2000). Towards the development of a reciprocal liaison service: A survey of attitudes. Psychiatric Bulletin, 24(10), 379-381.

De Hert, M., Cohen, D., Bobes, J., Cetkovich-Bakmas, M., Leucht, S., Ndetei, D. M., et al. (2011). Physical illness in patients with severe mental disorders II. Barriers to care, monitoring and treatment guidelines, plus recommendations at the system and individual level. World Psychiatry, 10, 138-151. 
De Hert, M., Correll, C., Bobes, J., Cetkovich-Bakmas, M., Cohen, D., Asai, I., et al. (2011). Physical illness in patients with severe mental disorders I. Prevalence, impact of medications and disparities in health care. World Psychiatry, 10, 52-77.

Dipasquale, S., Pariante, C.M., Dazzan, P., Aguglia, E., McGuire, P., Mondelli, V. (2013) The dietary pattern of patients with schizophrenia: A systematic review. Journal of Psychiatric Research. 47(2), 197-207.

Druss, B. G., Zhao, L., Von Esenwein, S., Morrato, E. H., \& Marcus, S. C. (2011). Understanding excess mortality in persons with mental illness: 17-year follow up of a nationally representative US survey. [Research Support, N.I.H., Extramural]. Medical Care, 49(6), 599-604.

Garden, G. (2005). Physical examination in psychiatric practice. Advances in Psychiatric Treatment, 11, 142-149.

Groves, R., \& Peytcheva, E. (2008). The impact of nonresponse rates on nonresponse bias: a meta-analysis. Public Opinion Quarterly, 72(2), 167-189.

Harper, B., \& Roman, B. (2017). The changing landscape of recruitment in psychiatry. Academic Psychiatry, 41(2), 221-225.

Hodgson, R., \& Adeyemo, O. (2004). Physical examination performed by psychiatrists. International Journal of Psychiatry in Clinical Practice, 8, 57-60.

Hodgson, R., Belgamwar, M., \& Krishna, S. (2006). Where's my stethoscope ? A survey of access to medical equipment. Progress in Neurology and Psychiatry 10, 9-11.

Imison, C., Castle-Clarke, S., \& Watson, R. (2016). Reshaping the workforce to deliver the care patients need. Research report: Nuffield Trust. 
Jones, S., Howard, L., \& Thornicroft, G. (2008). 'Diagnostic overshadowing' : worse physical care for people with mental illness. Acta Psychiatrica Scandinavica, 118, 169-171. doi: 0.1111/j.1600-0447.2008.01211.x

Lawrence, D., Hancock, K. J., \& Kisely, S. (2013). The gap in life expectancy from preventable physical illness in psychiatric patients in Western Australia: retrospective analysis of population based registers. [Research Support, Non-U.S. Gov't]. British Medical Journal, 346, f2539. doi: 10.1136/bmj.f2539

Livingston, E., \& Wislar, J. (2012). Minimum response rates for survey research. Archives of Surgery, 147(2), 110.

Madan, R., Conn, D., Dubo, E., Voore, P., \& Wiesenfeld, L. (2012). The enablers and barriers to the use of direct observation of trainee clinical skills by supervising faculty in a psychiatry residency program. Canadian Journal of Psychiatry, 57(4), 269-272.

Murray, J., \& Baillon, S. (2013). A case series of physical examinations on psychiatric inpatients: influence of a structured form on the quality of documentation. Journal of Mental Health, 22(5), 428-438.

Murray, J., Baillon, S., Bruce, J., \& Velayudhan, L. (2015). A survey of psychiatrists' attitudes towards the physical examination. Journal of Mental Health, 24(4), 249-254. doi: $10.3109 / 09638237.2015 .1057320$

Patel, M., Robson, D., Rance, J., Ramirez, N., Memon, T., Bressington, D., et al. (2009). Attitudes regarding mental health nurse prescribing among psychiatrists and nurses : A cross-sectional questionnaire study. International Journal of Nursing Studies, 46(1), 1467-1474.

Pettipher, A., \& Ovens, R. (2015). The psychiatric inpatient physical health assessment sheet (PIPHAS): a useful tool to improve the speed, efficiency, and documentation of 
physical examination in new psychiatric inpatients. BMJ Quality Improvement Reports, 4(1). doi: 10.1136/bmjquality.u206294.w2558

Phelan, M., Stradins, L., \& Morrison, S. (2001). Physical health of people with severe mental illness. British Medical Journal, 322, 443-444.

Reeves, R. R., Pendarvis, E. J., \& Kimble, R. (2000). Unrecognized medical emergencies admitted to psychiatric units. [Research Support, Non-U.S. Gov't]. American Journal of Emergency Medicine, 18(4), 390-393.

Rigby, J. C., \& Oswald, A. G. (1986). An evaluation of the performing and recording of physical examinations by psychiatric trainees. British Journal of Psychiatry, 150, 533535.

Shah, P., \& Mountain, D. (2007). The medical model is dead - long live the medical model. . British Journal of Psychiatry, 191, 375-377.

Sokal, J., Messias, E., Dickerson, F., Kreyenbuhl, J., Brown, C., Goldberg, R., et al. (2004). Comorbidity of medical illnesses among adults with serious mental illness who are receiving community psychiatric services. Journal of Nervous and Mental Disorders, $192,421-427$.

The Royal College of Psychiatrists. (2009). Physical health in mental health. Final report of a scoping group. Occasional Paper OP67. London: Royal College of Psychiatrists.

The Royal College of Psychiatrists. (2013). Whole-Person Care: From Rhetoric to Reality (Achieving Parity Between Mental and Physical Health) (OP88). London: Royal College of Psychiatrists.

Thornicroft, G. (2013). Premature death among people with mental illness. British Medical Journal, 346, f2969. doi: 10.1136/bmj.f2969 
Vancampfort, D., Stubbs, B., Mitchell, A.J., de Hert, M., Wampers, M., Ward, P.B., Rosenbaum, S., Correll, C.U. (2015) Risk of metabolic syndrome and its components in people with schizophrenia and related psychotic disorders, bipolar disorder and major depressive disorder: a systematic review and meta-analysis. World Psychiatry. 14(3), 339-47.

Vancampfort, D., Correll, C.U., Galling, B., Probst, M., De Hert, M., Ward, P.B., Rosenbaum, S., Gaughran, F., Lally, J., Stubbs, B. (2016) Diabetes mellitus in people with schizophrenia, bipolar disorder and major depressive disorder: a systematic review and large scale meta-analysis. World Psychiatry. 15(2), 166-74.

Vancampfort, D., Firth, J., Schuch, F.B., Rosenbaum, S., Mugisha, J., Hallgren, M., Probst, M., Ward, P.B., Gaughran, F., De Hert, M., Carvalho, A.F., Stubbs, B. (2017) Sedentary behavior and physical activity levels in people with schizophrenia, bipolar disorder and major depressive disorder: a global systematic review and meta-analysis. World Psychiatry. 16(3), 308-315.

Vanezis, A., \& Manns, D. (2010). Physical examinations of mental health services users. Progress in Neurology and Psychiatry, 14(4), 19-23.

Waern, M., Rubenowitz, E., Runeson, B., Skoog, I., Wilhelmson, K., \& Allebeck, P. (2002). Burden of illness and suicide in elderly people: case-control study. [Research Support, Non-U.S. Gov't]. British Medical Journal, 324(7350), 1355. 
Table 1. Speciality and Grade of respondents* (Total $N=2072)$

\begin{tabular}{|c|l|l|}
\hline & $\begin{array}{l}\text { N responded } \\
\text { to item }\end{array}$ & N (\%) \\
\hline Speciality & 2072 & \\
- General Adult & & $948(45.8)$ \\
- Old Age & & $407(19.6)$ \\
- Child \& Adolescent & $260(12.5)$ \\
- Learning Difficulties & $169(8.2)$ \\
- Addictions & & $85(4.1)$ \\
- Forensic & & $177(8.5)$ \\
- Eating Disorders & $59(2.8)$ \\
- Early Intervention & & $35(1.7)$ \\
- Liaison & & $111(5.4)$ \\
- Psychotherapy & & $71(3.4)$ \\
- Neuropsychiatry & & $75(2.2)$ \\
- Rehabilitation \& Assertive Outreach & & $27(1.3)$ \\
- Perinatal & & \\
\hline Grade & & $1198(57.8)$ \\
- Consultant & & $251(12.1)$ \\
- Non-consultant career grade & $71(3.4)$ \\
- Professor, Lecturer or Research Fellow & & $179(8.6)$ \\
- Senior trainee & & $337(16.3)$ \\
- Psychiatric core trainee & $3(0.1)$ \\
- GP or Foundation trainee & & \\
\hline
\end{tabular}

* $16 \%$ of respondents selected more than one speciality

Table 2. Frequency of conducting PE

\begin{tabular}{|c|c|c|c|c|}
\hline & \multirow{2}{*}{$\begin{array}{l}\mathrm{N} \text { responded } \\
\text { to item }\end{array}$} & \multicolumn{2}{|c|}{ Grade $^{1}$} & \multirow{3}{*}{$\begin{array}{l}\mathrm{N}(\%) \\
682(33.0)\end{array}$} \\
\hline & & Senior $^{2}$ & Junior & \\
\hline $\begin{array}{llll}\text { Routinely } & \text { perform } & \text { PE } & \text { on } \\
\text { inpatients } & & & \\
\end{array}$ & 2072 & $375 / 1324$ & $294 / 340$ & \\
\hline 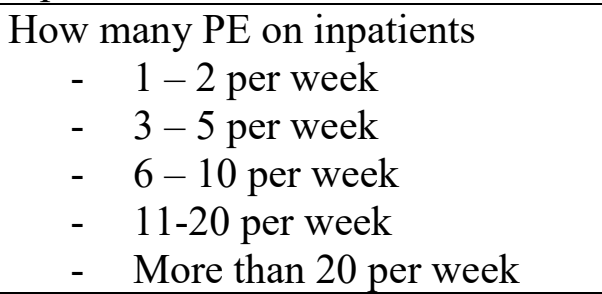 & 685 & $\begin{array}{l}190 \\
89 \\
33 \\
4 \\
1\end{array}$ & $\begin{array}{l}161 \\
92 \\
25 \\
4 \\
0\end{array}$ & $\begin{array}{l}356(58.6) \\
185(30.4) \\
58(9.5) \\
8(1.3) \\
1(0.2)\end{array}$ \\
\hline $\begin{array}{llll}\begin{array}{l}\text { Routinely } \\
\text { outpatients }\end{array} & \text { perform } & \text { PE } & \text { on } \\
\end{array}$ & 2066 & $165 / 1530$ & $35 / 338$ & $203(9.8)$ \\
\hline $\begin{array}{l}\text { How many PE on outpatients } \\
\begin{aligned}- & 1-2 \text { per week } \\
- & 3-5 \text { per week } \\
- & 6-10 \text { per week } \\
- & 11-20 \text { per week } \\
- & \text { More than } 20 \text { per week }\end{aligned}\end{array}$ & 195 & $\begin{array}{l}83 \\
37 \\
15 \\
3 \\
1\end{array}$ & $\begin{array}{l}14 \\
6 \\
3 \\
0 \\
0\end{array}$ & $\begin{array}{l}98(59.4) \\
45(27.3) \\
18(10.9) \\
3(1.8) \\
1(0.6)\end{array}$ \\
\hline
\end{tabular}

${ }^{1}$ where grade had been indicated by respondent

2 Senior $=$ Consultant, non-consultant career grade, Professor, Lecturer or Research Fellow, or senior trainee; Junior $=$ Psychiatric core trainee or GP or Foundation trainee 
Table 3 - Frequency of survey question responses $($ Total sample $=\mathbf{2 0 7 2})$

\begin{tabular}{|c|c|c|c|c|c|}
\hline Experiences of PE in psychiatry & Response & $\begin{array}{l}\mathrm{N} \\
\text { responded }\end{array}$ & $\begin{array}{l}\text { Freq } \\
\text { (valid \%) }\end{array}$ & $\begin{array}{l}\mathrm{N} \\
\text { responded }\end{array}$ & $\begin{array}{l}\text { Freq } \\
\text { (valid \%) }\end{array}$ \\
\hline In your current job, do you perform physical examinations? & $\begin{array}{l}\text { Yes } \\
\text { No } \\
\end{array}$ & 2072 & \begin{tabular}{|l|l}
$682(32.9)$ \\
$1390(67.1)$ \\
\end{tabular} & 2066 & \begin{tabular}{|l|}
$203(9.8)$ \\
$1863(90.2)$ \\
\end{tabular} \\
\hline $\begin{array}{l}\text { Whilst performing a physical examination, do you have: } \\
-\quad \text { Adequate time? } \\
-\quad \text { Adequate equipment? } \\
-\quad \text { Examination couch? } \\
\text { - Access to a chaperone? }\end{array}$ & $\begin{array}{l}\text { Yes } \\
\text { Yes } \\
\text { Yes } \\
\text { Yes }\end{array}$ & $\begin{array}{l}661 \\
658 \\
658 \\
657 \\
\end{array}$ & $\begin{array}{l}556(84.1) \\
325(49.4) \\
437(66.4) \\
608(92.5)\end{array}$ & $\begin{array}{l}183 \\
181 \\
181 \\
180\end{array}$ & $\begin{array}{l}127(69.4) \\
106(58.6) \\
107(59.1) \\
127(70.6)\end{array}$ \\
\hline $\begin{array}{l}\text { How would you describe the reaction of most patients to the physical } \\
\text { examination? }\end{array}$ & $\begin{array}{l}\text { Positive } \\
\text { Neutral } \\
\text { Negative }\end{array}$ & 663 & $\begin{array}{l}258(38.9) \\
334(50.4) \\
61(9.2)\end{array}$ & 180 & $\begin{array}{l}101(56.1) \\
75(41.7) \\
4(2.2)\end{array}$ \\
\hline $\begin{array}{l}\text { Whilst performing a physical examination on a psychiatric patient how } \\
\text { often do you feel intimidated? }\end{array}$ & $\begin{array}{l}\text { Always } \\
\text { Usually } \\
\text { Sometimes } \\
\text { Rarely } \\
\text { Never } \\
\end{array}$ & 663 & $\begin{array}{l}1(0) \\
53(8.0) \\
282(42.5) \\
247(37.3) \\
71(10.7)\end{array}$ & 182 & $\begin{array}{l}1(0) \\
3(1.6) \\
23(12.6) \\
89(48.9) \\
66(36.3)\end{array}$ \\
\hline
\end{tabular}


Table 4 - Frequency of survey question responses $($ Total sample $=2072)$

\begin{tabular}{|c|c|c|c|}
\hline Opinions about PE in psychiatry & Response & $\mathbf{N}$ & \% of valid responses \\
\hline How would you rate the importance of the physical examination in psychiatry? & $\begin{array}{l}\text { Essential } \\
\text { Important } \\
\text { Slightly useful } \\
\text { Unimportant } \\
\text { Totally irrelevant }\end{array}$ & 2022 & $\begin{array}{l}874(43.2) \\
919(45.5) \\
209(10.3) \\
18(0.9) \\
2(0.1)\end{array}$ \\
\hline $\begin{array}{l}\text { Do you think that a patient's mental state should have a bearing on the type of } \\
\text { physical examination that a psychiatrist performs? }\end{array}$ & $\begin{array}{l}\text { Yes } \\
\text { No } \\
\text { Not sure }\end{array}$ & 2021 & $\begin{array}{l}1796(88.9) \\
150(7.4) \\
75(3.7)\end{array}$ \\
\hline $\begin{array}{l}\text { Do you think it would be helpful if clear gold standards were set for the different } \\
\text { types of physical examinations (e.g. full, limited or external inspection only) a } \\
\text { psychiatrist performs? }\end{array}$ & $\begin{array}{l}\text { Yes } \\
\text { No } \\
\text { Not sure }\end{array}$ & 2017 & $\begin{array}{l}1206(59.8) \\
423(21.0) \\
388(19.2)\end{array}$ \\
\hline $\begin{array}{l}\text { Are you in favour of using a structured form (proforma) to record the findings of } \\
\text { the physical examination? }\end{array}$ & $\begin{array}{l}\text { Yes } \\
\text { No } \\
\text { Not sure }\end{array}$ & 2027 & $\begin{array}{l}1342(66.2) \\
458(22.6) \\
227(11.2)\end{array}$ \\
\hline PE Skills & Response & $\mathbf{N}$ & \% of valid responses \\
\hline $\begin{array}{l}\text { How would you rate your proficiency in performing a physical examination of a } \\
\text { psychiatric patient? }\end{array}$ & $\begin{array}{l}\text { Very good } \\
\text { Good } \\
\text { Mediocre } \\
\text { Poor } \\
\text { Very poor } \\
\end{array}$ & 2000 & $\begin{array}{l}224(11.2) \\
932(46.6) \\
670(33.5) \\
136(6.8) \\
38(1.9) \\
\end{array}$ \\
\hline $\begin{array}{l}\text { Since starting work in psychiatry, have your physical examination skills improved, } \\
\text { remained the same or deteriorated? }\end{array}$ & $\begin{array}{l}\text { Improved } \\
\text { Remained the same } \\
\text { Deteriorated }\end{array}$ & 2006 & $\begin{array}{l}175(8.7) \\
608(30.3) \\
1223(61.0) \\
\end{array}$ \\
\hline $\begin{array}{l}\text { Do you think that the ability to perform an adequate physical examination should } \\
\text { be a part of a psychiatrist's core competencies? }\end{array}$ & $\begin{array}{l}\text { Yes } \\
\text { No } \\
\text { Not sure }\end{array}$ & 2000 & $\begin{array}{l}1653(82.7) \\
159(8.0) \\
188(9.4)\end{array}$ \\
\hline $\begin{array}{l}\text { Do you think that Psychiatrists should have to maintain their physical examination } \\
\text { skills throughout their career e.g. by attending refresher courses? }\end{array}$ & $\begin{array}{l}\text { Yes } \\
\text { No } \\
\text { Not sure }\end{array}$ & 1996 & $\begin{array}{l}1379(69.1) \\
288(14.4) \\
329(16.5)\end{array}$ \\
\hline
\end{tabular}




\begin{tabular}{|c|c|c|c|}
\hline $\begin{array}{l}\text { Do you think that a teaching session on the physical examination in psychiatry } \\
\text { should be included in the psychiatric trainees' induction course? }\end{array}$ & $\begin{array}{l}\text { Yes } \\
\text { No } \\
\text { Not sure }\end{array}$ & 1995 & $\begin{array}{l}1472(73.8) \\
354(17.7) \\
169(8.5)\end{array}$ \\
\hline $\begin{array}{l}\text { Do you think that the physical examinations performed on psychiatric patients } \\
\text { should be done by another type of professional e.g. a physician, or a psychiatric } \\
\text { nurse practitioner? }\end{array}$ & $\begin{array}{l}\text { Yes } \\
\text { No } \\
\text { Not sure }\end{array}$ & 2003 & $\begin{array}{l}552(27.6) \\
907(45.3) \\
544(27.6)\end{array}$ \\
\hline Training and supervision of PE skills & Response & $\mathbf{N}$ & $\%$ of valid responses \\
\hline Are you currently in a training post? & $\begin{array}{l}\text { Yes } \\
\text { No }\end{array}$ & 2006 & $\begin{array}{l}503(25.1) \\
1503(74.9)\end{array}$ \\
\hline Have your PE skills been directly observed by your supervisor in the last year? & $\begin{array}{l}\text { Yes } \\
\text { No }\end{array}$ & 499 & $\begin{array}{l}45(9.0) \\
454(91.0)\end{array}$ \\
\hline How would you rate the quality of this supervision? & $\begin{array}{l}\text { Very good } \\
\text { Good } \\
\text { Mediocre } \\
\text { Poor } \\
\text { Very poor }\end{array}$ & 47 & $\begin{array}{l}15(31.9) \\
26(55.3) \\
4(8.5) \\
2(4.3) \\
0\end{array}$ \\
\hline Do your duties currently involve the clinical supervision of psychiatric trainees? & $\begin{array}{l}\text { Yes } \\
\text { No }\end{array}$ & 1502 & $\begin{array}{l}943(62.8) \\
559(37.2)\end{array}$ \\
\hline $\begin{array}{l}\text { Have you directly observed the physical examination skills of your trainee(s) } \\
\text { during the last year? }\end{array}$ & $\begin{array}{l}\text { Yes } \\
\text { No }\end{array}$ & 934 & $\begin{array}{l}284(30.4) \\
650(69.6)\end{array}$ \\
\hline $\begin{array}{l}\text { Reasons for not conducting supervision in this area } \\
\text { - Lack of confidence in my abilities in this domain } \\
\text { - The belief that trainee's skills in this domain are better than my own } \\
\text { - The view that other topics are more important } \\
\text { - Practical difficulties in arranging observation of PE skills } \\
\text { - Other reasons }\end{array}$ & $\begin{array}{l}\text { Yes } \\
\text { Yes } \\
\text { Yes } \\
\text { Yes } \\
\text { Yes }\end{array}$ & $\begin{array}{l}555 \\
581 \\
551 \\
585 \\
522\end{array}$ & $\begin{array}{l}157(28.3) \\
324(55.8) \\
217(39.4) \\
407(69.6) \\
306(58.6)\end{array}$ \\
\hline How would you rate your ability to supervise trainees in this domain? & $\begin{array}{l}\text { Very good } \\
\text { Good } \\
\text { Mediocre } \\
\text { Poor } \\
\text { Very poor }\end{array}$ & 921 & $\begin{array}{l}74(8.0) \\
414(45.0) \\
340(36.9) \\
75(8.1) \\
18(2.0) \\
\end{array}$ \\
\hline
\end{tabular}


